The Journal of Animal \& Plant Sciences, 30(4): 2020, Page: 931-943

ISSN (print): 1018-7081; ISSN (online): 2309-8694

\title{
GENETIC DIVERSITY AND MOLECULAR TAXONOMY STUDY OF GENUS FESTUCA
}

\author{
A. Alsaleh ${ }^{1 *}$, M. C. Doğrusoz ${ }^{2}$, U. Basaran ${ }^{2}$, A. Tamkoc ${ }^{3}$ and M. A. Avci ${ }^{3}$ \\ ${ }^{1}$ Science and Technology Application and Research Center (BILLTEM), Yozgat Bozok University, Yozgat, Turkey. \\ ${ }^{2}$ Department of Field Crops, Faculty of Agricultural, Yozgat Bozok University, Yozgat, Turkey. \\ ${ }^{3}$ Department of Field Crops, Faculty of Agricultural, Selcuk University, Konya, Turkey. \\ Corresponding author E-mail: ahmad.alsaleh@bozok.edu.tr
}

\begin{abstract}
The genus Festuca (Poaceae) occupies a wide range of lands in both hemispheres, with astounding significance endowed by the genetic diversity, intra/inter-species discriminations, and structure analysis of Fescue species based on a reliable molecular marker. While still in the infancy stage, information on genetic structure and relationships of Festuca species from Turkish gene pool have rarely, or never, been subjected to the most needed studies. Six species of genus Festuca were put in the limelight. A total of 598 loci were generated through molecular characterization of 68 accessions by using 19 inter-simple sequence repeats primers. Molecular variance revealed a variation within species and among species of $75 \%$ and 25 , respectively. The $F$. ovina showed high values in relation to the number of different alleles, Shannon's information index, and percentage of polymorphic loci. The highest genetic variability, expected and unbiased expected heterozygosity values were detected for $F$. arundinacea. Nei genetic distance showed that the lowest value was found between $F$. ovina and $F$. valesiaca species, while the highest was identified between $F$. heterophylla and $F$. pratensis species. An obvious convergence has been detected through Principal Coordinate Analysis, neighbor-joining dendrogram and Structure output, with accessions divided into number-of- species-based groups. The study resulted in implications for genetic revision, which, in turn, may clear the misty vision that geneticists might have regarding fescue; and could be exploited in future genetic resources conservation and breeding programs.
\end{abstract}

Key words: Festuca, genetic diversity, genetic structure, ISSR, Molecular marker, phylogenetic.

https://doi.org/10.36899/JAPS.2020.4.0109

Published online April 25, 2020

\section{INTRODUCTION}

Festuca (Poaceae), one of the most complex genera of Poaceae, presents a cosmopolitan distribution worldwide with over 600 species of multiple ploidy levels ranging from diploid $(2 n=2 x=14)$ up to dodecaploid $(2 n=12 x=84)$ (Cheng et al., 2016). This widespread genus is well adapted to diverse climatic conditions and soil types across the temperate zones and utilized as pasture turf grass and in erosion control (Gibson and Newman, 2001). In Turkey, Festuca is represented by 52 species (Guner, 2012). Tall fescue ( $F$. arundinacea $\mathrm{Schreb}$ ), is the most important $\mathrm{C} 3$ species of bunchgrass, commonly described with three major morphotypes (Continental, Mediterranean and rhizomatous) showing a significant variation in terms of agronomic, morphological and physiological traits (Hand et al., 2010). Tall fescue varieties have been developed mainly for forage production, while turf-type varieties that are designated for recreational uses have been developed from several different species ( $F$. ovina $L$., $F$. arundinacea, $F$. rubra and $F$. pratensis) (Demiroğlu et al., 2010; Hand et al., 2010; Ogle et al., 2010; Özpinar et al., 2014).

Festuca arundinacea shows high genetic diversity and tolerance to a broad range of habitats and environmental conditions (Cuyeu et al., 2013). It has numerous cultivars, which makes it a highly important pasture grass. In addition, $F$. arundinacea is important in the Mediterranean region, and locally dominant species of arid zonal meadows (Gibson and Newman, 2001). Five such species ( $F$. filiformis Pourret, $F$. idahoensis Elmer, F. ovina L. ssp. hirtula (Hackel ex Travis) M. Wilkinson, $F$. trachyphylla (Hackel) Krajina, and F. valesiaca Schleich. ex Gaudin) form the Festuca ovina aggregate that is often called the "ovina complex". Species within the $F$. ovina complex are cross compatible and, thus, hybrids between these and other Festuca species can occur frequently in nature (Ma, 2012). The species $F$. ovina may harbor novel variations for crop improvement, while the red fescue ( $F$. rubra), characterized by a strong tillering capacity, and seems to be more suitable as a pasture plant (Özpinar et al., 2014).

Taxonomically, fescue is one of the most complex genera in the Poaceae family with substantial morphological, phylogenic and anatomic variation. Genetic variability of individuals varies from one population to another (Balkan, 2018). Although the genetic variability has been earlier reported in tall fescue (F. arundinacea Schreb.) by Nelson et al. (1975) with the taxonomic classification of the genus described by many researchers, this matter has not been solved clearly yet 
(Hand et al., 2012). This necessitates a further investigation of the taxonomic relationships among the species of this genus using molecular markers. Characterization of germplasm belonging to different species of this genus must be in place as a first step, with the genetic structure and diversity at the inter/intra-genus level understood at the DNA level. DNA molecular analysis significantly contributes to characterization at the genetic and/or molecular level (Alsaleh et al., 2016). Among the several molecular marker techniques developed over the past two decades, the technique of inter simple sequence repeats (ISSR) markers remains attractive for genetic research so far. It is quick, low cost and easy to handle dominant genetic marker system. This marker system was developed by Zietkiewicz et al. (1994) and used for studying the genetic diversity, phylogeny, gene tagging, genome mapping and evolutionary biology studies (Reddy et al., 2002). ISSR is a semi-arbitrary marker; amplified by polymerase chain reaction (PCR). It does not require genome sequence information and leads to multi-locus and highly polymorphous patterns (Nadeem et al., 2018). ISSR markers have been used for genetic diversity assessment and phylogenetic relationships in many different species such as fine-leaved fescue (Armoniene et al., 2010; Kumar et al., 2014; Lamare and Rao, 2015; Stukonis et al., 2015), P. pratensis (Szenejko et al., 2016) and in many different crops such as chickpea (Andeden et al., 2013), lentil (Baloch et al., 2015), soybean and peanut (Baloch et al., 2010) alfalfa (Habibi et al., 2012), wheat (Abou-Deif et al., 2013), barley (Rahimi et al., 2014) and rice (Al-Turki et al., 2015).

Information available on genetic resources and the related geographical locations can be used to gain insight into population divergence. Phenotypic divergence among fescue populations has been described earlier, with particular attention paid to some of the tall fescue populations; while genetic diversity has been the subject of multiple studies in different parts of the world (Armoniene et al., 2010; Ma, 2012; Stukonis et al., 2015; Cheng et al., 2016; Zhang et al., 2017; Akbari et al., 2018; Rahmati et al., 2018; Talukder et al., 2018). Although Turkey is considered as hotspot zone of origin and domestication of many species under the genus of Poaceae (Baloch et al., 2017), no information describing the genetic structure of the Festuca species from the Turkish gene pool has been found in literature so far. Therefore, the objective of this study was to bridge in the gap, as well as to evaluate the genetic diversity, determining species structure and understanding the phylogenetic and genetic relationships among six Festuca species.

\section{MATERIALS AND METHODS}

Plant material: A panel of 68 fescue (Festuca L.) accessions belonging to 6 different species including 37 accessions of $F$. ovina, $13 F$. arundinacea, $12 F$. valesiaca, two each of $F$. heterophylla $F$. rubra, and $F$. pratensis, collected from a diverse range of 17 different provinces and various ecological conditions in Turkey have been used as a plant material in this study. Full details of these accessions are presented in Table 1.

DNA extraction: Total genomic DNA was isolated from young leaves according to QIAGEN kit (DNeasy Plant Mini kit, Valencia, California). The extracted DNA was qualitatively and quantitatively evaluated, and measured by $0.8 \%$ Agarose gel electrophoresis. Before using DNA for PCR analysis, the concentrated DNA was diluted to a $10 \mathrm{ng} / \mu \mathrm{l}$.

ISSR-PCR: To detect their polymorphism level, a total of 50 ISSR primers were first screened on four DNA of randomly selected accessions of different species. The primers that showed poor or no patterns were discarded and those showing clear bands with higher allelic frequencies were selected. 19 polymorphic ISSR primers were selected and screened for the whole set of accessions. Information about the ISSR primers used in this study is briefly described in Table 2 .

PCR amplifications were carried out according to the protocol of Zietkiewicz et al. (1994). PCR amplification of ISSRs was performed in a $10 \mu 1$ PCR mix of approximately $50 \mathrm{ng}$ genomic DNA, $0.4 \mathrm{mM}$ dNTPs, 0.8 pmol ISSR primers, $0.2 \mathrm{U}$ of Taq DNA polymerase and 1X PCR buffer (10 mM Tris $\mathrm{HCl} \mathrm{pH} \mathrm{8.3,50} \mathrm{mM}$ $\mathrm{KCl}, 3 \mathrm{mM} \mathrm{MgCl}_{2}$ ). The Eppendorf Mastercycler (Germany) was programmed for an initial denaturation step of $94^{\circ} \mathrm{C}$ for $2 \mathrm{~min}$, followed by 40 cycles at $94^{\circ} \mathrm{C}$ for $1 \mathrm{~min}$, at the specific annealing temperature of each primer (as described in Table 2 ), $72^{\circ} \mathrm{C}$ for $2 \mathrm{~min}$ and a final extension at $72^{\circ} \mathrm{C}$ for $10 \mathrm{~min}$, ahold temperature of $4^{\circ} \mathrm{C}$ at the end was applied.

According to their molecular weight, the ISSRPCR products were separated by Fisher scientific electrophoresis chamber (UK) on 2.5\% Agarose gels submerged in $1 \mathrm{X}$ TBE buffer and accompanied with a standard size marker 100 bp DNA Ladder (Jena Bioscience $\mathrm{GmbH}$, Germany) for molecular size estimations. They were finally stained with ethidium bromide solution $(0.5 \mu \mathrm{g} / \mathrm{ml}$ final concentration $)$ for 20 min. PCR fragments were visualized on UV transilluminator using the Gel Documentation System (VILBER, Quantum, France).

Data analysis: The amplified 598 ISSR loci were scored and checked twice using Cross Checker 2.91 as described by Buntjer (1999). ISSR markers were scored as binary data $(1 / 0)$, indicating the presence $(1)$ or absence $(0)$ of a 
marker in the genomic representation of each sample; data are constructed in a binary matrix. For each primer, polymorphism information content value (PIC) has been calculated by MS Excel using PIC $=1-\left[\mathrm{f}^{2}+(1-\mathrm{f})^{2}\right]$ formula, where (f) is the marker frequency in the data set (Chesnokov and Artemyeva, 2015). Principal Coordinate Analysis (PCoA), Analysis of Molecular Variance (AMOVA) and other diversity analysis were performed using computer software program GenAlEx 6.1 (Peakall and Smouse, 2001). A Cluster analysis of all accessions has been made using the DARWin 6.0.13 software (Perrier et al., 2003) as per the neighbor-joining method is attributed to Sokal and Michener (1958).

The population structure was performed with the STRUCTURE v.2.3.4 software (Pritchard et al., 2000) with a model-based clustering method applied. The structure analysis was carried out with $\mathrm{K}=10,20000$ burning length and 50,000 reps over 10 iterations, then the results were run in the Structure Harvester version 0.6.94 software (Earl and Von Holdt, 2012) to estimate the number of subpopulations $(K)$. Delta $K(\Delta K)$ is based on the rate of change in the log probability of data between successive $\mathrm{K}$ values. This was used to determine the number of clusters $(\mathrm{K})$ in the population (Evanno et al., 2005).

\section{RESULTS AND DISCUSSION}

Molecular variance and population diversity analysis: For genetic diversity and genetic evaluation, the dominant data would be robust for studying population structuring and genetic differentiation among populations, where the molecular markers such as ISSR are more effective because they present a lot of details on genetic difference at the DNA level. Therefore, extensive information about the genetic diversity of genus Festuca collected from many eco-geographical regions is expected to have a remarkable impact on the preservation and usage of genus Festuca. A total of 68 accessions belonging to 6 species of Festuca were screened with nineteen polymorphic ISSR primers, with a total of 598 polymorphic bands produced. The fragment size varied from 400 to $4000 \mathrm{bp}$. The highest amplified fragment number (46) was produced by IS6 primer, while the lowest bands (16) were displayed by IS16, with an average of 31.5 fragments per primer. The informativeness of the ISSR markers was estimated by the PIC values ranged from 0.07 (UBC844) to 0.21 (IS6) with an average of 0.15 (Table 2), which is lower than the average PIC value of 0.33 reported by Rahmati et al., (2018) using ISSR markers, lower than the value of 0.21 identified by Zhang et al., (2017) using Amplified Fragment Length Polymorphism (AFLP) and lower than the PIC values of 0.27 and 0.22 obtained using genomic SSR and EST-SSR (Tehrani et al., 2009).
To detect species differentiation using molecular markers, all data were analyzed for the frequency and the overall distribution of alleles among and within the suggested groups. Comparison of AMOVA in all species clearly demonstrated that groups within a given comparison have genetically a higher degree of differentiation than when contrasted among groups. This was reflected by the higher proportion of total variance for the 'within' (75\%) and for the 'among' (25\%) analyses. These results is consistent with the analysis reported by Zhang et al. (2017) (77.8\%) and (20.7\%), respectively. Other studies also reveal a high proportion of total variance for the within populations, for example, Kumar et al. (2014) reported 92.2\% variance within populations and $7.8 \%$ variance among $J$. adhatoda populations. This could be interpreted that genus Festuca is a polyploidy complex, or that out-crossing species would favor the maintenance of high levels of intraaccession genetic diversity (Zhang et al., 2017).

The diversity parameters were also investigated for the whole species, $F$. ovina showed the highest values in three of the diversity parameters such as No. of different alleles (Na), Shannon's information index (I), and Percentage of Polymorphic Loci (PPL), with values of $1.492,0.157$, and $74.6 \%$, respectively. The highest values $(1.130,0.090$ and 0.094$)$ of No. of effective alleles $(\mathrm{Ne})$, expected heterozygosity (He), and unbiased expected heterozygosity (uHe) were detected in $F$. arundinacea, respectively (Table 3 ). On the other hand, $F$. valesiaca showed a significant number of effective alleles detected by the primer IS12. While for $F$. arundinacea the highest value was detected by the primer IS6. Other primers IS1, IS9, UBC808, UBC812, and UBC864 showed the same value of $(\mathrm{Ne})$, but for $F$. rubra, and $F$. ovina, the highest value was detected by UBC741, with similar results reported by Fasih et al. (2013). Thus, these primers will be advantageous and helpful to easily distinguish the fescue species.

Actually, the understanding of the genetic relationships among fescue species would improve the understanding of evolutionary relationships among Festuca species (Ma, 2012). With F. ovina accessions exceeding $54 \%$ of the total studied number, because its importance where high tolerance to stress, abundance, and perseveration in multiple environments (Zhang et al., 2017), each species has been grouped into portions of variant proportions. This factor may have a positive effect on the high diversity parameter values $(\mathrm{Na}, \mathrm{I}$, and PPL) noticed for $F$. ovina, while it may has negatively affected other species which contained a fewer number of accessions. For example, the number of $F$. arundinacea accessions (13 accessions) in our study was slightly higher than that of $F$. valesiaca accessions (12 accessions); differences have been observed between these two species, where $F$. arundinacea showed higher values in all genetic parameters. Similarly, a small 
number of accessions may arguably lose large amounts of genetic variation, where, for example, by comparing $F$. heterophylla, F. rubra and $F$. pratensis, three species of the same accessions number, $F$. pratensis showed higher values of the whole diversity parameters compared to $F$. heterophylla and F. rubra. While; comparing these species of 'two accessions' with species of bigger accessions numbers low genetic diversity values obviously have been obtained. Overgrazing and human over exploitation may trigger a rising trend in irregular distribution and isolation of this species, with low genetic diversity revealed (Table 3 ).

Genetic distance and neighbor joining tree: The genetic divergence between species was measured as genetic distance. The pairwise population matrix of the Nei genetic distance showed that the lowest genetic distance was found between $F$. ovina and $F$. valesiaca species (0.012), while the highest genetic distance was observed between $F$. heterophylla and $F$. pratensis species (0.060) (Table 4). Genetic distance was calculated also between whole accessions by applying DARWin software, showed that the minimum value (0.083) was noticed between the accessions of No: 54 and 55 from $F$. valesiaca specie collected from the same place (Kayseri-Tuzla Golu), while the maximum distance value was noticed between two accessions collected from same location (Adana-Pozant1) but from different species, accession with accession number of 32 belonging to $F$. ovina and the accession with accession number of 65 belonging to $F$. rubra (Figure 1). Genetic distance average within the whole collection is 0.126 (0.083 $0.9166)$. These values are close to their counterparts of 0.1094 (0.0802 - 0.1508) reported by Zhang et al. (2017), and lower than the value of 0.369 identified by Szenejko et al. (2016) for P. pratensis L only. The average of genetic distance identified among $F$. ovina accessions (0.815) showed higher value than those of $F$. arundinacea and $F$. valesiaca accessions, (0.708) and (0.585), respectively (data not shown).

Correlation coefficients between the genetic diversity parameters and an average of altitude values of collection areas of the accessions were calculated and have been negative generally with zero significance, where high altitudes were correlated obviously with low genetic diversity parameters and confirmed, where some of biotic and/or abiotic factors could be the reasons behind, and this result is consistent with Zhang et al. (2017) (Table 5).

In addition, to check and confirm the genetic variations for each species, the genetic distance based neighbor joining dendrogram was constructed, with results showing clear diversity among accessions from each species. Accessions were splatted into the three main clusters: A, B and C. Cluster (A) is contained two sub-clusters; A-1 consists mainly of $F$. ovina and A-2 composed of $F$. valesiaca. Cluster B was divided also into two sub-clusters, $F$. arundinacea was present in B-1 and $F$. pratensis in B-2, but convergence among two different species $F$. heterophylla and $F$. rubra noted at C1 cluster, confirming the clear convergence and overlapped noted among these species (Figure 1). The species $F$. ovina and $F$. valesiaca have all been gathered within cluster A, while $F$. arundinacea and $F$. pratensis within cluster B, F. heterophylla and F. rubra have been gathered within cluster $\mathrm{C}$, indicating their association. These results were compatible with the calculated genetic distance values for these species, where the Nei genetic distance values were the lowest for these species 0.012 , 0.029 , and 0.020 , respectively (Table 4). Ma (2012) considers $F$. valesiaca and $F$. ovina as one species in the $F$. ovina complex. Despite of the discrete genetic entities, much research carried out for decades has revealed an affinity between many fescues species. Borrill et al. (1977) suggests that $F$. pratensis is one progenitor of $F$. arundinacea. In addition, Malik \& Thomas (1967), Xu and Sleper (1994), Rouf Mian et al. (2005), Hand et al. (2010), Angelov \& Ivanova (2012), Ma (2012) and Cheng et al. (2016) all confirmed their close relationship, with $F$. arundinacea as the most relevant species, which is evolution-wise close to other $F$. pratensis species. On the other hand, Bulifiska-Radomska and Lester (1986) confirm the association between $F$. rubra and $F$. heterophylla.

Despite the fact that grouping does not show a full relationship with geographical origin, it partially confirms with their geographical source, whereas this relationship confirms in many sub-clusters (Figure 1). The reason behind this could be associated with many factors, which are the gene flow, out-crossing and ploidy level difference. The analyses, therefore, relatively indicates that accessions weakly categorized on the basis of geographical origin, and that geographical convergence factor may be the reason behind the prominent similarity that indicates a close relationship among them, with a common progenitor probably existing.

Principal Coordinate Analysis: In order to identify the relationships within and among species, Principal Coordinate Analysis was carried out using the dominant genotypic distance and the covariance-standardized methodology to elucidate the patterns of species structure. The first two principal coordinates were drawn in a two-dimensional space graph to show the clustering of different accessions. The percentage of accessions variations explained by the first 3 axes were $15.69 \%$, $5.52 \%$ and $5.38 \%$ of the variance, respectively with a percentage of cumulative $15.69 \%, 21.21 \%$, and $26.59 \%$, respectively. While higher of percentage found of species variations explained by the first 3 axes were $81.27 \%$, $10.55 \%$ and $5.37 \%$ of the variance, respectively with a 
percentage of cumulative $81.27 \%, 91.82 \%$, and $97.19 \%$, respectively. The accessions were divided simply into many species-specific groups; $F$. ovina accessions were gathered at "A" group; $F$. arundinacea accessions were located at "B", the third "C" for $F$. valesiaca, "D" group represents $F$. heterophylla accessions, "E" group for $F$. rubra and "F" for $F$. pratensis accessions (Figure 2). Furthermore, the PCoA results are consistent with the neighbor-joining clusters and with the genetic distance, as well. Similarly to AMOVA analysis in PCoA, a high diversity has been clearly identified within species, although the accessions have been collected from a varying range of different provinces and ecological conditions in Turkey, the PCoA diagram also showed that their proliferation was very close or indicates they are gathered according to each species. Whereas an obvious convergence among some species has been noticeable also particularly for $F$. heterophylla and $F$. rubra accessions (Figure 2). The relationships among the six species were also visualized by PCoA and demonstrated in Figure 3. Likewise, a consistency between PCoA result and that of Neighbor-Joining tree, as well as a clear genetic differentiation also have been clearly noticed, confirming the clear convergence and indicating high probability that has a progenitor common with those species.

Defining population structure: Numerous biometrical models have been developed for population stratification (Zhu et al., 2008). A favorite method to detect population structure has been introduced by Pritchard et al. (2000), in which, molecular marker information has been used to assign group membership probabilities to the genotypes utilizing a Bayesian framework. Genetic distance and genetic relationships among the Festuca panel are therefore, graphically investigated via PCoA, and by neighbor-joining cluster analyses. These are used as complementary approaches to confirm the results obtained using STRUCTURE. Different accessions belonging to various species have been assigned to the related groups as per the membership of coefficient (Q matrices). Accessions having a membership of coefficient (Q matrices) greater than 0.5 are assigned to related group. The optimal number of populations $(K)$ was derived by $\Delta K$ values (Evanno et al., 2005), the highest value of $\Delta K$ was observed at $K=3$, is shown $64.7 \%$ of the accessions have a complex genetic structure (Figure 4 ). Minute details of the second highest value of $\Delta K$ is shown at $\mathrm{K}=6$, which corresponded to the number of sub-populations, where the accessions were classified into eight groups, the accessions were lined up and obviously gathered based on related species, comprise a "simple" or "simple and admixture" pattern genetic structure, while the other groups are of "complex" or "complex and admixture" pattern of a genetic structure (Figure 4). For example, group IV was simple pattern of a genetic structure consisted of $F$. arundinacea, while group I was simple pattern, but has been indicating admixture also between $F$. valesiaca, $F$. heterophylla and $F$. rubra carrying a large dark red segment for membership coefficient, leads to confirm their relationship and suggests that genetic structure composition of this group is substantially affected by the alleles introduced from $F$. valesiaca. However, $70.6 \%$ of the accessions have a complex genetic structure, where groups II complex structure pattern restricted to $F$. valesiaca, while groups III, VI, VII and VIII consisted of $F$. ovina are complex also with no admixture noticed. The other group, $\mathrm{V}$ in addition to complex structure pattern, showed admixture of various alleles with two different species $F$. arundinacea and $F$. pratensis, introduced from species with an ancestral crossing parent in their lineages (Figure 5). At $\mathrm{K}=6$ the estimated Ln Prob $=8988.9$, with a standard deviation of 390.1, mean value of $\mathrm{Ln}$ likelihood $=-7359.1$, variance of $\mathrm{Ln}$ likelihood $=3259.6$ and mean value of $\alpha=0.0374$. High value was noticed for average of six population differentiation Fst 51.7\% $(12.8 \%-97.1 \%)$ with SE of 0.1196 . The average genetic variability of species determined in this study $(51.7 \%)$ was higher than FsT value of $(20.71 \%)$ reported by Zhang et al. (2017) and by Fjellheim et al. (2004) for both the Norwegian meadow fescue populations and Nordic cultivars. High variability value determined in our study indicating high diversity, and has been probably affected by using different molecular markers, DNA strategies, or habitat fragmentation, where random genetic drift over time has managed to both enter genetic differentiation, and cause a loss of heterozygosity within the population. However, it is necessary to keep in mind that structure and all other Bayesian methods are modelbased, with strong priors and hypotheses, and all limitations and restrictions of these approaches considered in terms of ensuring a correct analysis of the results.

On the other hand, $F$. ovina and $F$. valesiaca accessions investigated in this study are spread in many different groups, probably due to the five different ploidy levels reported by Šmarda et al. (2005), the six subspecies existed according to Sheidai and BagheriShabestarei (2007), or to some other reasons. Generally, the examined species have shown that the groups are in good agreement in terms of the result of the PCoA and neighbor-joining analysis. 
Table 1. The list of accessions, Species, Collection place, Latitude, Longitude and Altitude.

\begin{tabular}{|c|c|c|c|c|c|}
\hline No & Species & Collection place & Latitude & Longitude & Altitude \\
\hline 1 & F.ovina & Konya Kent Ormani & $37^{\circ} 53.351 \mathrm{~N}$ & $032^{\circ} 12.581 \mathrm{E}$ & $1530 \mathrm{~m}$ \\
\hline 2 & F.ovina & Konya Kiziloren & $37^{\circ} 51.571 \mathrm{~N}$ & $032^{\circ} 06.033 \mathrm{E}$ & $1433 \mathrm{~m}$ \\
\hline 3 & F.ovina & Korkuteli & $36^{\circ} 31.892 \mathrm{~N}$ & $029^{\circ} 59.445 \mathrm{E}$ & $1043 \mathrm{~m}$ \\
\hline 4 & F.ovina & Kayseri & $38^{\circ} 36.098 \mathrm{~N}$ & $035^{\circ} 30.595 \mathrm{E}$ & $1884 \mathrm{~m}$ \\
\hline 5 & F.ovina & Konya Kiziloren & $37^{\circ} 51.571 \mathrm{~N}$ & $032^{\circ} 06.033 \mathrm{E}$ & $1433 \mathrm{~m}$ \\
\hline 6 & F.ovina & Antalya-Alanya & $36^{\circ} 51.589 \mathrm{~N}$ & $032^{\circ} 31.228 \mathrm{E}$ & $1734 \mathrm{~m}$ \\
\hline 7 & F.ovina & Antalya-Korkuteli & $36^{\circ} 58.406 \mathrm{~N}$ & $030^{\circ} 09.097 \mathrm{E}$ & $1224 \mathrm{~m}$ \\
\hline 8 & F.ovina & Antalya-Korkuteli & $36^{\circ} 53.255 \mathrm{~N}$ & $030^{\circ} 02.478 \mathrm{E}$ & $1188 \mathrm{~m}$ \\
\hline 9 & F.ovina & Antalya-Alanya & $36^{\circ} 51.589 \mathrm{~N}$ & $032^{\circ} 31.228 \mathrm{E}$ & $1734 \mathrm{~m}$ \\
\hline 10 & F.ovina & Seydisehir-Tinaztepe & $37^{\circ} 16.097 \mathrm{~N}$ & $031^{\circ} 54.997 \mathrm{E}$ & $1642 \mathrm{~m}$ \\
\hline 11 & F.ovina & Konya Kiziloren & $37^{\circ} 51.571 \mathrm{~N}$ & $032^{\circ} 06.033 \mathrm{E}$ & $1433 \mathrm{~m}$ \\
\hline 12 & F.ovina & Konya Kiziloren & $37^{\circ} 51.571 \mathrm{~N}$ & $032^{\circ} 06.033 \mathrm{E}$ & $1433 \mathrm{~m}$ \\
\hline 13 & F.ovina & Kizilcahamam & $40^{\circ} 40.534 \mathrm{~N}$ & $032^{\circ} 19.500 \mathrm{E}$ & $1251 \mathrm{~m}$ \\
\hline 14 & F.ovina & Karaman & $36^{\circ} 42.073 \mathrm{~N}$ & $032^{\circ} 25.534 \mathrm{E}$ & $1696 \mathrm{~m}$ \\
\hline 15 & F.ovina & Karabuk-Kastamonu & $41^{\circ} 21.323 \mathrm{~N}$ & $033^{\circ} 39.731 \mathrm{E}$ & $1177 \mathrm{~m}$ \\
\hline 16 & F.ovina & Corum & $40^{\circ} 33.000 \mathrm{~N}$ & $034^{\circ} 57.000 \mathrm{E}$ & $801 \mathrm{~m}$ \\
\hline 17 & F.ovina & Corum & $40^{\circ} 33.000 \mathrm{~N}$ & $034^{\circ} 57.000 \mathrm{E}$ & $801 \mathrm{~m}$ \\
\hline 18 & F.ovina & Corum & $40^{\circ} 33.000 \mathrm{~N}$ & $034^{\circ} 57.000 \mathrm{E}$ & $801 \mathrm{~m}$ \\
\hline 19 & F.ovina & Adana Kadirli-Karatepe & $37^{\circ} 16.025 \mathrm{~N}$ & $036^{\circ} 13.276 \mathrm{E}$ & $305 \mathrm{~m}$ \\
\hline 20 & F.ovina & Adana Kadirli-Karatepe & $37^{\circ} 16.025 \mathrm{~N}$ & $036^{\circ} 13.276 \mathrm{E}$ & $305 \mathrm{~m}$ \\
\hline 21 & F.ovina & Adana Kadirli-Karatepe & $37^{\circ} 16.025 \mathrm{~N}$ & $036^{\circ} 13.276 \mathrm{E}$ & $305 \mathrm{~m}$ \\
\hline 22 & F.ovina & Adana-Pozant1-Akcatekir & $37^{\circ} 23.820 \mathrm{~N}$ & $034^{\circ} 50.962 \mathrm{E}$ & $905 \mathrm{~m}$ \\
\hline 23 & F.ovina & Adana-Pozant1-Akcatekir & $37^{\circ} 23.820 \mathrm{~N}$ & $034^{\circ} 50.962 \mathrm{E}$ & $905 \mathrm{~m}$ \\
\hline 24 & F.ovina & Adana-Pozantı & $37^{\circ} 21.648 \mathrm{~N}$ & $034^{\circ} 48.800 \mathrm{E}$ & $1242 \mathrm{~m}$ \\
\hline 25 & F.ovina & Adana-Pozantı & $37^{\circ} 21.648 \mathrm{~N}$ & $034^{\circ} 48.800 \mathrm{E}$ & $1242 \mathrm{~m}$ \\
\hline 26 & F.ovina & Adana-Pozantı & $37^{\circ} 21.648 \mathrm{~N}$ & $034^{\circ} 48.800 \mathrm{E}$ & $1242 \mathrm{~m}$ \\
\hline 27 & F.ovina & Adana-Pozant1 & $37^{\circ} 21.648 \mathrm{~N}$ & $034^{\circ} 48.800 \mathrm{E}$ & $1242 \mathrm{~m}$ \\
\hline 28 & F.ovina & Adana-Pozantı & $37^{\circ} 21.648 \mathrm{~N}$ & $034^{\circ} 48.800 \mathrm{E}$ & $1242 \mathrm{~m}$ \\
\hline 29 & F.ovina & Adana-Pozant1 & $37^{\circ} 21.648 \mathrm{~N}$ & $034^{\circ} 48.800 \mathrm{E}$ & $1242 \mathrm{~m}$ \\
\hline 30 & F.ovina & Adana-Pozant1 & $37^{\circ} 21.648 \mathrm{~N}$ & $034^{\circ} 48.800 \mathrm{E}$ & $1242 \mathrm{~m}$ \\
\hline 31 & F.ovina & Adana-Pozant1 & $37^{\circ} 21.648 \mathrm{~N}$ & $034^{\circ} 48.800 \mathrm{E}$ & $1242 \mathrm{~m}$ \\
\hline 32 & F.ovina & Adana-Pozantı & $37^{\circ} 21.648 \mathrm{~N}$ & $034^{\circ} 48.800 \mathrm{E}$ & $1242 \mathrm{~m}$ \\
\hline 33 & F.ovina & Adana-Pozantı & $37^{\circ} 21.648 \mathrm{~N}$ & $034^{\circ} 48.800 \mathrm{E}$ & $1242 \mathrm{~m}$ \\
\hline 34 & F.ovina & Ankara-Elmadag & $40^{\circ} 37.014 \mathrm{~N}$ & $032^{\circ} 30.504 \mathrm{E}$ & $1387 \mathrm{~m}$ \\
\hline 35 & F.ovina & Ankara-Elmadag & $40^{\circ} 37.014 \mathrm{~N}$ & $032^{\circ} 30.504 \mathrm{E}$ & $1387 \mathrm{~m}$ \\
\hline 36 & F.ovina & Ankara-Elmadag & $40^{\circ} 37.014 \mathrm{~N}$ & $032^{\circ} 30.504 \mathrm{E}$ & $1387 \mathrm{~m}$ \\
\hline 37 & F.ovina & Adana Kadirli-Karatepe & $37^{\circ} 16.025 \mathrm{~N}$ & $036^{\circ} 13.276 \mathrm{E}$ & $305 \mathrm{~m}$ \\
\hline 38 & F.arundinacea & Cankiri & $40^{\circ} 36.000 \mathrm{~N}$ & $033^{\circ} 36.600 \mathrm{E}$ & $750 \mathrm{~m}$ \\
\hline 39 & F.arundinacea & Bolu Kartepe & $40^{\circ} 39.674 \mathrm{~N}$ & $030^{\circ} 08.019 \mathrm{E}$ & $1520 \mathrm{~m}$ \\
\hline 40 & F.arundinacea & Konya Kent Ormani & $37^{\circ} 53.351 \mathrm{~N}$ & $032^{\circ} 12.581 \mathrm{E}$ & $530 \mathrm{~m}$ \\
\hline 41 & F.arundinacea & Bursa & $40^{\circ} 08.120 \mathrm{~N}$ & $029^{\circ} 01.498 \mathrm{E}$ & $956 \mathrm{~m}$ \\
\hline 42 & F.arundinacea & Kastamonu & $41^{\circ} 06.732 \mathrm{~N}$ & $033^{\circ} 44.978 \mathrm{E}$ & $1355 \mathrm{~m}$ \\
\hline 43 & F.arundinacea & Yozgat & $39^{\circ} 51.607 \mathrm{~N}$ & $034^{\circ} 55.494 \mathrm{E}$ & $1285 \mathrm{~m}$ \\
\hline 44 & F.arundinacea & Kizilcahamam & $40^{\circ} 40.534 \mathrm{~N}$ & $032^{\circ} 19.500 \mathrm{E}$ & $1251 \mathrm{~m}$ \\
\hline 45 & F.arundinacea & Antalya-Akseki & $37^{\circ} 07.290 \mathrm{~N}$ & $031^{\circ} 49.118 \mathrm{E}$ & $1281 \mathrm{~m}$ \\
\hline 46 & F.arundinacea & Antalya-Akseki & $37^{\circ} 07.290 \mathrm{~N}$ & $031^{\circ} 49.118 \mathrm{E}$ & $1281 \mathrm{~m}$ \\
\hline 47 & F.arundinacea & Ankara-Kizilcahamam & $40^{\circ} 40.534 \mathrm{~N}$ & $032^{\circ} 19.500 \mathrm{E}$ & $1251 \mathrm{~m}$ \\
\hline 48 & F.arundinacea & Konya-Kampus & $38^{\circ} 36.577 \mathrm{~N}$ & $031^{\circ} 07.646 \mathrm{E}$ & $984 \mathrm{~m}$ \\
\hline 49 & F.arundinacea & Konya-Kampus & $38^{\circ} 36.577 \mathrm{~N}$ & $031^{\circ} 07.646 \mathrm{E}$ & $984 \mathrm{~m}$ \\
\hline 50 & F.arundinacea & Konya-Kampus & $38^{\circ} 36.577 \mathrm{~N}$ & $031^{\circ} 07.646 \mathrm{E}$ & $984 \mathrm{~m}$ \\
\hline 51 & F.valesiaca & Ankara-Kizilcahamam & $40^{\circ} 37.014 \mathrm{~N}$ & $032^{\circ} 30.504 \mathrm{E}$ & $1387 \mathrm{~m}$ \\
\hline 52 & F.valesiaca & Kayseri & $38^{\circ} 36.098 \mathrm{~N}$ & $035^{\circ} 30.595 \mathrm{E}$ & $1884 \mathrm{~m}$ \\
\hline 53 & F.valesiaca & Kayseri/Tuzla Golu & $38^{\circ} 57.658 \mathrm{~N}$ & $035^{\circ} 45.614 \mathrm{E}$ & $1324 \mathrm{~m}$ \\
\hline 54 & F.valesiaca & Kayseri/Tuzla Golu & $38^{\circ} 57.658 \mathrm{~N}$ & $035^{\circ} 45.614 \mathrm{E}$ & $1324 \mathrm{~m}$ \\
\hline 55 & F.valesiaca & Kayseri/Tuzla Golu & $38^{\circ} 57.658 \mathrm{~N}$ & $035^{\circ} 45.614 \mathrm{E}$ & $1324 \mathrm{~m}$ \\
\hline 56 & F.valesiaca & Kayseri & $38^{\circ} 36.098 \mathrm{~N}$ & $035^{\circ} 30.595 \mathrm{E}$ & $1884 \mathrm{~m}$ \\
\hline
\end{tabular}




\begin{tabular}{|c|c|c|c|c|c|}
\hline 57 & F.valesiaca & Konya-Antalya & $37^{\circ} 08.884 \mathrm{~N}$ & $031^{\circ} 53.313 \mathrm{E}$ & $1541 \mathrm{~m}$ \\
\hline 58 & F.valesiaca & Konya-Antalya & $37^{\circ} 08.884 \mathrm{~N}$ & $031^{\circ} 53.313 \mathrm{E}$ & $1541 \mathrm{~m}$ \\
\hline 59 & F.valesiaca & Konya-Basarakavak & $37^{\circ} 53.510 \mathrm{~N}$ & $032^{\circ} 18.579 \mathrm{E}$ & $1268 \mathrm{~m}$ \\
\hline 60 & F.valesiaca & Konya-Aksehir Beysehir & $37^{\circ} 08.411 \mathrm{~N}$ & $031^{\circ} 47.805 \mathrm{E}$ & $1204 \mathrm{~m}$ \\
\hline 61 & F.valesiaca & Adana-Pozantı & $37^{\circ} 21.648 \mathrm{~N}$ & $034^{\circ} 48.800 \mathrm{E}$ & $1242 \mathrm{~m}$ \\
\hline 62 & F.valesiaca & Ankara & $40^{\circ} 37.014 \mathrm{~N}$ & $032^{\circ} 30.504 \mathrm{E}$ & $1387 \mathrm{~m}$ \\
\hline 63 & F.heterophylla & Kizilcahamam & $40^{\circ} 40.534 \mathrm{~N}$ & $032^{\circ} 19.500 \mathrm{E}$ & $1251 \mathrm{~m}$ \\
\hline 64 & F.heterophylla & Kizilcahamam-Gerede & $40^{\circ} 37.014 \mathrm{~N}$ & $032^{\circ} 30.504 \mathrm{E}$ & $1387 \mathrm{~m}$ \\
\hline 65 & F.rubra & Adana Pozantı & $37^{\circ} 21.648 \mathrm{~N}$ & $034^{\circ} 48.800 \mathrm{E}$ & $1242 \mathrm{~m}$ \\
\hline 66 & F.rubra & Mersin-Tarsus & $37^{\circ} 11.375 \mathrm{~N}$ & $034^{\circ} 48.534 \mathrm{E}$ & $699 m$ \\
\hline 67 & F.pratensis & Yozgat & $39^{\circ} 51.607 \mathrm{~N}$ & $034^{\circ} 55.494 \mathrm{E}$ & $1285 \mathrm{~m}$ \\
\hline 68 & F.pratensis & Konya-Cevizli & $37^{\circ} 12.169 \mathrm{~N}$ & $031^{\circ} 46.334 \mathrm{E}$ & $1111 \mathrm{~m}$ \\
\hline
\end{tabular}

Table 2. ISSR primers used for screening of polymorphism, their Sequences, Annealing temperatures, Fragment sizes and numbers as well as their Polymorphic Index contents.

\begin{tabular}{|c|c|c|c|c|c|}
\hline Primer name & $\begin{array}{c}\text { Sequences } \\
5^{\prime}-3^{\prime}\end{array}$ & $\mathbf{T m}$ & Fragments size (bp) & Fragments Number & PIC \\
\hline G07 & $(\mathrm{GAA})_{5} \mathrm{CG}$ & 47 & $400-3500$ & 31 & 0.16 \\
\hline G11 & $(\mathrm{AC})_{8} \mathrm{CG}$ & 47 & $410-3200$ & 35 & 0.15 \\
\hline IS1 & $(\mathrm{GA})_{8} \mathrm{C}$ & 52 & $1000-3200$ & 23 & 0.16 \\
\hline IS5 & $(\mathrm{AG})_{8} \mathrm{C}$ & 52 & $575-3000$ & 28 & 0.19 \\
\hline IS6 & $\mathrm{DBD}(\mathrm{AC})_{7} \mathrm{~A}$ & $49-56$ & $420-3500$ & 46 & 0.21 \\
\hline IS9 & $(\mathrm{GA})_{8} \mathrm{YC}$ & $54-56$ & $540-4000$ & 31 & 0.18 \\
\hline IS10 & $(\mathrm{AC})_{8} \mathrm{YA}$ & $51-54$ & $575-3500$ & 25 & 0.11 \\
\hline IS12 & $(\mathrm{AG})_{8} \mathrm{YT}$ & $51-54$ & $550-3200$ & 38 & 0.12 \\
\hline IS13 & $(\mathrm{GACA})_{4}$ & 48 & $580-3500$ & 29 & 0.15 \\
\hline IS16 & $(\mathrm{AC})_{8} \mathrm{C}$ & 52 & $680-3100$ & 16 & 0.16 \\
\hline UBC807 & $(\mathrm{AG})_{8} \mathrm{~T}$ & 50 & $580-3000$ & 32 & 0.18 \\
\hline UBC 808 & $(\mathrm{AG})_{8} \mathrm{C}$ & 52 & $550-3000$ & 35 & 0.15 \\
\hline UBC812 & $(\mathrm{GA})_{8} \mathrm{~A}$ & 50 & $540-3000$ & 29 & 0.14 \\
\hline UBC826 & $(\mathrm{AC})_{8} \mathrm{C}$ & 52 & $550-2800$ & 36 & 0.16 \\
\hline UBC841 & $(\mathrm{GA})_{8} \mathrm{YC}$ & $54-56$ & $560-4000$ & 45 & 0.19 \\
\hline UBC842 & $(\mathrm{GA})_{8} \mathrm{YG}$ & $54-56$ & $520-3500$ & 30 & 0.12 \\
\hline UBC844 & $(\mathrm{CT})_{8} \mathrm{RC}$ & $54-56$ & $730-3300$ & 24 & 0.07 \\
\hline UBC847 & $(\mathrm{CA})_{8} \mathrm{RC}$ & $54-56$ & $580-3200$ & 38 & 0.14 \\
\hline UBC864 & $(\mathrm{ATG})_{6}$ & 47 & $595-2000$ & 27 & 0.13 \\
\hline Min & & & 400 & 16 & 0.07 \\
\hline Max & & & 4000 & 46 & 0.21 \\
\hline Average & & & & 31.5 & 0.15 \\
\hline Total & & & & 598 & \\
\hline
\end{tabular}

Tm: Annealing Temperature, PIC: polymorphism information content

Table 3. Genetic parameters, Mean and standard Error over Loci for each population, Grand Mean and SE over Loci of studies species.

\begin{tabular}{|c|c|c|c|c|c|c|c|}
\hline Pop & & $\mathbf{N a}$ & $\mathrm{Ne}$ & I & He & uHe & PPL\% \\
\hline \multirow[t]{2}{*}{ F. ovina } & Mean & 1.492 & 1.102 & 0.157 & 0.082 & 0.084 & 74.6 \\
\hline & SE & 0.036 & 0.005 & 0.006 & 0.004 & 0.004 & \\
\hline \multirow[t]{2}{*}{ F. arundinacea } & Mean & 0.866 & 1.130 & 0.151 & 0.090 & 0.094 & 43.3 \\
\hline & $\mathrm{SE}$ & 0.041 & 0.009 & 0.008 & 0.005 & 0.006 & \\
\hline \multirow[t]{2}{*}{ F. valesiaca } & Mean & 0.314 & 1.082 & 0.075 & 0.049 & 0.052 & 15.7 \\
\hline & SE & 0.030 & 0.009 & 0.008 & 0.005 & 0.005 & \\
\hline \multirow[t]{2}{*}{ F. heterophylla } & Mean & 0.080 & 1.018 & 0.015 & 0.010 & 0.014 & 2.5 \\
\hline & $\mathrm{SE}$ & 0.014 & 0.005 & 0.004 & 0.003 & 0.004 & \\
\hline \multirow[t]{2}{*}{ F. rubra } & Mean & 0.119 & 1.035 & 0.030 & 0.021 & 0.028 & 5.0 \\
\hline & SE & 0.019 & 0.006 & 0.005 & 0.004 & 0.005 & \\
\hline F. pratensis & Mean & 0.134 & 1.040 & 0.034 & 0.024 & 0.031 & 5.7 \\
\hline
\end{tabular}




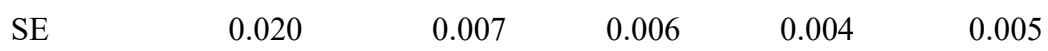

\begin{tabular}{lccccccc}
\hline Grand Mean and SE over Loci and Pops & & & & & \\
Total & Mean & 0.501 & 1.068 & 0.077 & 0.046 & 0.050 & 24.5 \\
& SE & 0.014 & 0.003 & 0.003 & 0.002 & 0.002 & 11.8 \\
\hline
\end{tabular}

$\mathrm{Na}=$ No. of different alleles, $\mathrm{Ne}=$ No. of effective Alleles, $\mathrm{I}=$ Shannon's information index, $\mathrm{He}=$ Expected heterozygosity, $\mathrm{uHe}=$ Unbiased expected heterozygosity, PPL $=$ Percentage of Polymorphic Loci, and SE $=$ standard error.

Table 4. Pairwise Species Matrix of Nei Genetic Distance.

\begin{tabular}{|c|c|c|c|c|c|c|}
\hline & F. ovina & F. arundinacea & F. valesiaca & F. heterophylla & F. rubra & F.pratensis \\
\hline F. ovina & 0.000 & & & & & \\
\hline$F$. arundinacea & 0.015 & 0.000 & & & & \\
\hline F. valesiaca & 0.012 & 0.023 & 0.000 & & & \\
\hline F. heterophylla & 0.040 & 0.048 & 0.046 & 0.000 & & \\
\hline F. rubra & 0.030 & 0.038 & 0.036 & 0.020 & 0.000 & \\
\hline F.pratensis & 0.028 & 0.029 & 0.033 & 0.060 & 0.050 & 0.000 \\
\hline
\end{tabular}

Table 5. Correlation coefficient between values of genetic diversity parameters and average of altitude values of the accession collection areas.

\begin{tabular}{|c|c|c|c|c|c|c|}
\hline & $\mathbf{N a}$ & $\mathrm{Ne}$ & I & He & uHe & PPL \\
\hline $\mathrm{Ne}$ & $0.787^{* *}$ & & & & & \\
\hline I & $0.934^{* *}$ & $0.955^{* *}$ & & & & \\
\hline He & $0.881^{* *}$ & $0.984^{* *}$ & $0.992^{* *}$ & & & \\
\hline uHe & $0.871^{* *}$ & $0.985^{* *}$ & $0.988^{* *}$ & $0.998^{* *}$ & & \\
\hline PPL & $0.999^{* *}$ & $0.795^{* *}$ & $0.938^{* *}$ & $0.887^{* *}$ & $0.877^{* *}$ & \\
\hline Altitude & -0.119 & -0.030 & -0.096 & -0.085 & -0.123 & -0.115 \\
\hline
\end{tabular}

$\mathrm{Ne}=$ No. of effective alleles, I = Shannon's information index, $\mathrm{He}=$ expected heterozygosity, $\mathrm{uHe}=$ unbiased expected heterozygosity, PPL $=$ Percentage of Polymorphic Loci.

*. Correlation is significant at the $\mathrm{P} \leq 0.05$ level, ${ }^{* *}$. Correlation is significant at the $\mathrm{P} \leq 0.01$ level.

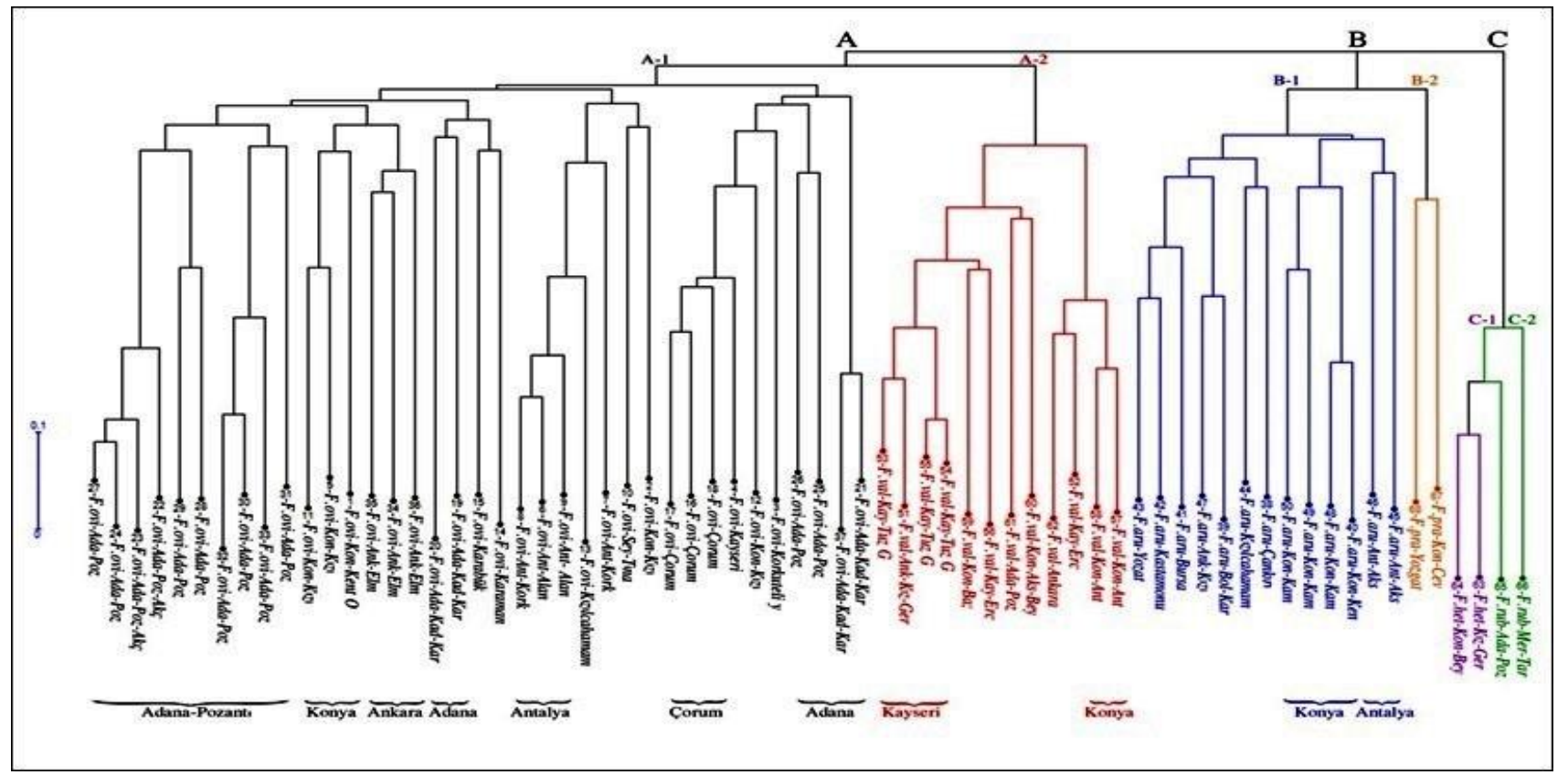

Figure 1. Neighbor-Joining tree showing relationships between 68 accessions revealed by overall genetic markers. The colors correspond to the species; black branches and names for $F$. ovina, blue for $F$. arundinacea, red for $F$. valesiaca, purple for $F$. heterophylla, green for $F$. rubra, and dark yellow for $F$. pratensis, the corresponding accessions numbers indicated at the bottom of the plot. 


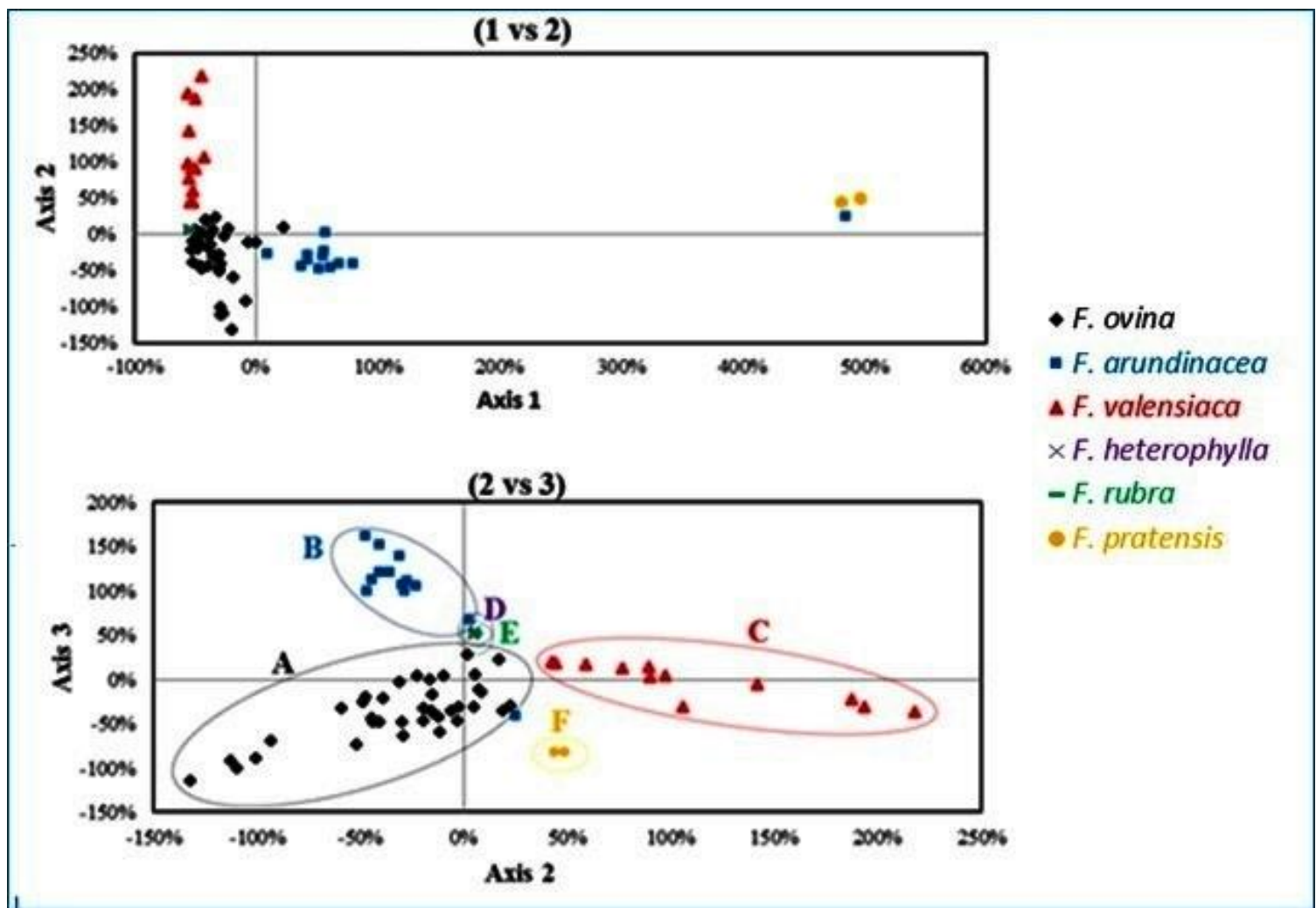

Figure 2. Relationship between accessions visualized by PCoA using ISSR markers.

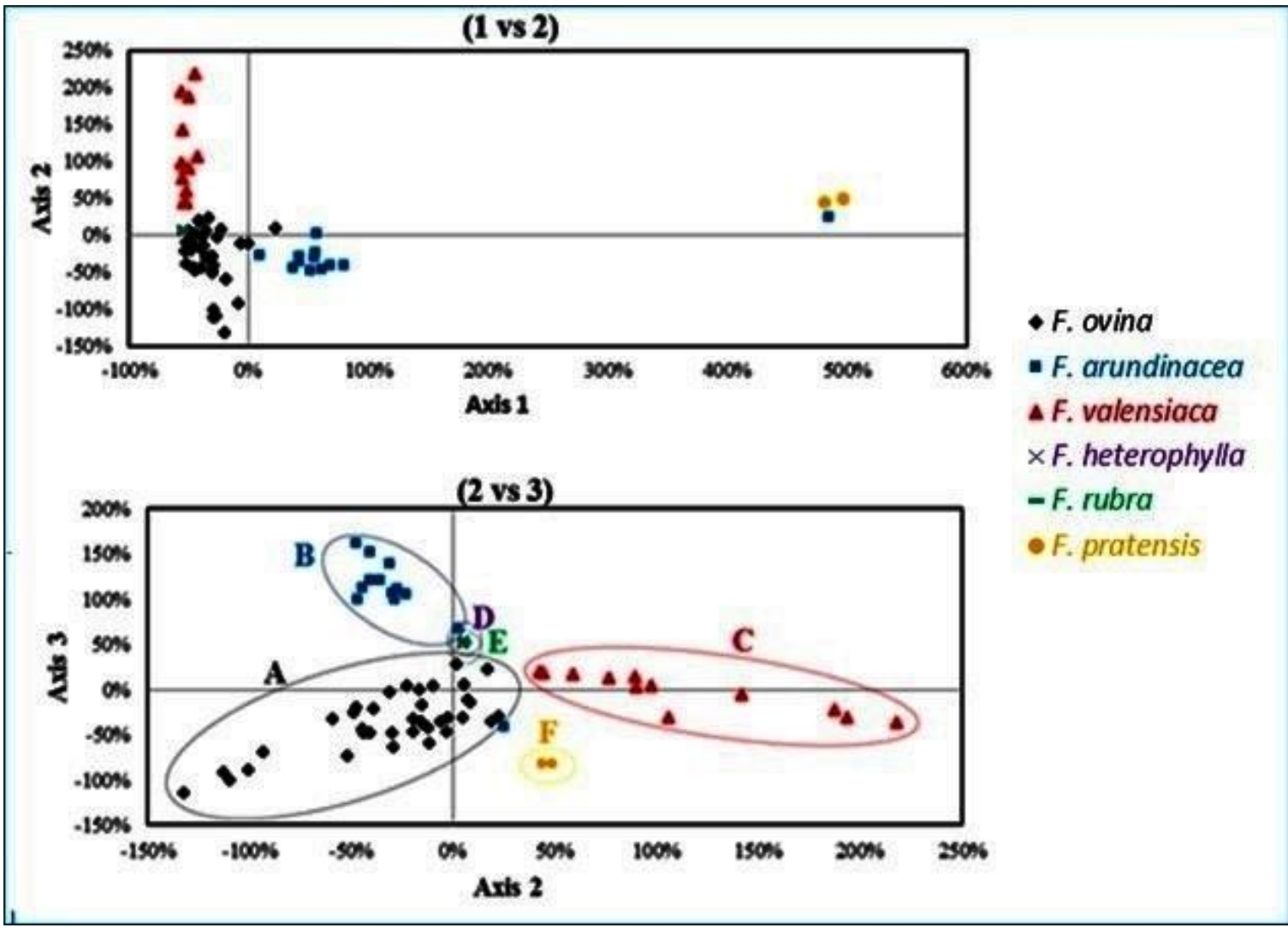

Figure 3. The relationships among six species based on the binary genetic distance visualized by PCoA. 


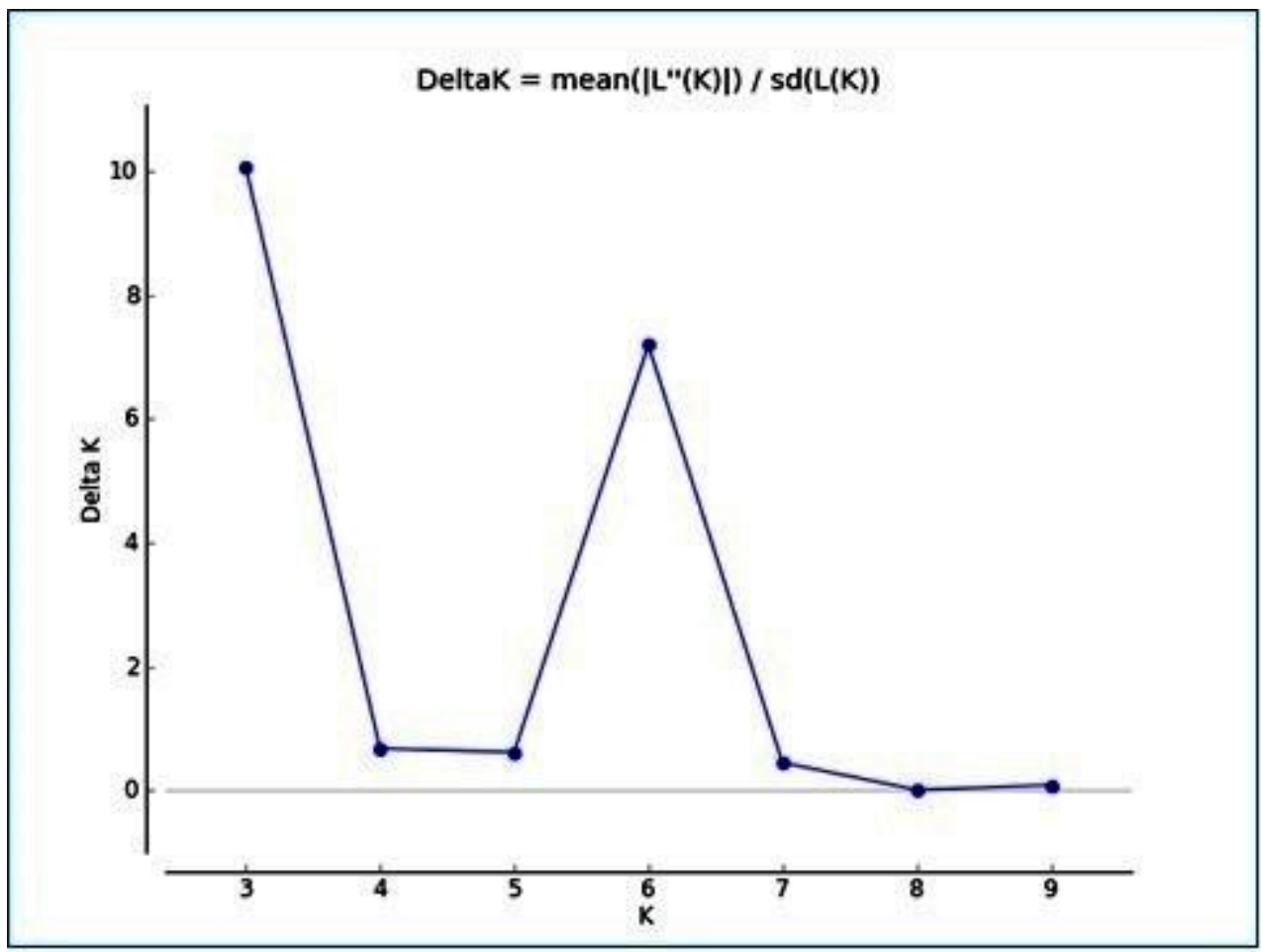

Figure 4. Inference of the optimal K value obtained from the STRUCTURE analysis of a dataset containing 68 Festuca accessions.

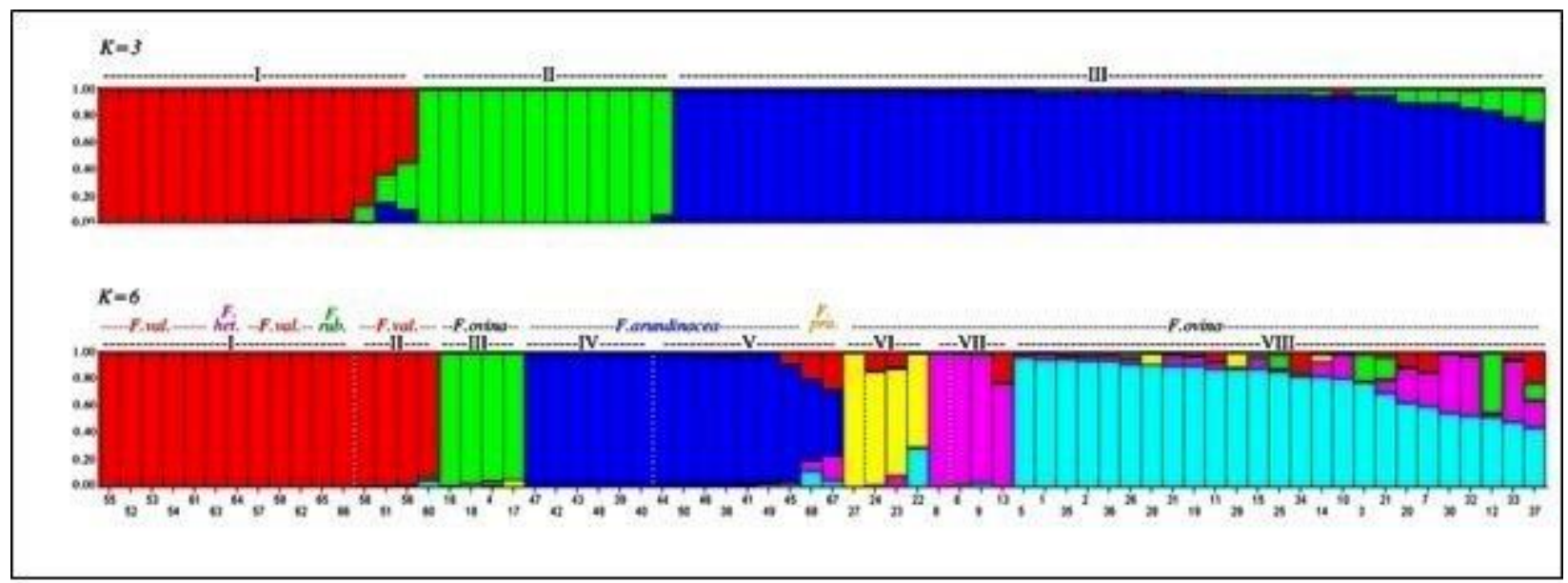

Figure 5. The survey of the genetic associations among 68 accessions using STRUCTURE. The models of $K=3$ and $\mathrm{K}=6$ showed the $\Delta \mathrm{K}$ value at the highest log-likelihood value. A vertical axis indicates a membership coefficient in each optimum number of $K$.

Conclusion: The study demonstrated genetic and taxonomic relationship among 6 species of genus Festuca using ISSR markers. A different statistical algorithm was used. An obvious convergence has been detected through PCoA, NJ tree, and Structure output, with accessions divided into number-of-species-based groups. F. ovina and $F$. valesiaca species showed the highest genetic relationship, while the highest genetic distance was identified between $F$. heterophylla and $F$. pratensis species. More deep studies are indispensable using next- generation sequencing based molecular markers covering the whole genome in order to get a clearer picture and revising the taxonomy of this complex genus.

Acknowledgements: The authors are grateful to Prof. Dr. Ruştu Hatipoğlu, University Cukurova, Adana, Turkey, for his contribution and valuable scientific inputs. 
The authors express their thanks also to Yozgat Bozok University, Scientific Research Projects Unit, for financial support (Project No. 6603c-ZF/17-128).

\section{REFERENCES}

Abou-Deif, M.H., M.A. Rashed, M.A.A. Sallam, E.A.H. Mostafa, and W.A. Ramadan (2013). Characterization of Twenty Wheat Varieties by ISSR Markers. Middle East J. Sci. Res. 15 (2): 168-175.

Akbari, M., H. Salehi, and A. Niazi (2018). Evaluation of Diversity Based on Morphological Variabilities and ISSR Molecular Markers in Iranian Cynodon dactylon (L.) Pers. Accessions to

Select and Introduce Cold-Tolerant Genotypes. Molecular Biotechnology. 60:259-270.

Alsaleh, A., F.S. Baloch, M. Nachit and, H. Ozkan (2016). Phenotypic and genotypic intra-diversity among Anatolian durum wheat "Kunduru" landraces, Biochem. Syst. Ecol. 65: 9-16.

Al-Turki, T.A., and M.A. Basahi (2015). Assessment of ISSR based molecular genetic diversity of Hassawi rice in Saudi Arabia. Saudi J. Biological Sciences. 22: 591-599.

Andeden, E.E., F.S. Baloch, B. Kilian, and H. Ozkan (2013). iPBS-retrotransposons based genetic diversity and relationship among wild annual Cicer species. J. Plant Biochem. Biotechnol. 22: 453-466.

Angelov, G. B., and T.A. Ivanova (2012). Isoenzyme variation and genetic affinities among four species of the genus Festuca L. (Poaceae) Biodiv. Res. Conserv. 28: 3-8.

Armoniene, R., V. Stukonis, V. Paplauskiene, and G. Brazauskas (2010). The Genetic Diversity of Fine-Leaved Fescue (Festuca L.) Species in Lithuania. C. Huyghe (ed), Sustainable Use of Genetic Diversity in Forage and Turf Breeding, Springer Science +Business Media B. V. 2010. P: 41-45.

Balkan, A. (2018). Genetic variability, heritability and genetic advance for yield and quality traits in M2-4 generations of bread wheat (Triticum Aestivum L.) genotypes. Turk J Field Crops. 23(2): 173-179.

Baloch, F.S., A. Alsaleh, M.Q. Shahid, V. Ciftci, L.E. Saenz de Miera, M. Aasim, M. A. Nadeem, H. Aktas, H. Ozkan, and R. Hatipoğlu (2017). A Whole Genome DArTseq and SNP Analysis for Genetic Diversity Assessment in Durum Wheat from Central Fertile Crescent. PLoS One. 12 (1).

Baloch, F.S., M. Derya, E.E. Andeden, A. Alsaleh, G. Comertpay, B. Kilian, and H. Ozkan (2015). Inter-primer binding site retrotransposon and inter-simple sequence repeat diversity among wild Lens species. Biochem. Syst. Ecol. 58: 162168.

Baloch, F.S., C. Kurt, H. Arıglu, and H. Ozkan (2010). Assaying of diversity among soybean (Glycin $\max$ L. Merr.) and peanut (Arachis hypogaea L.) genotypes at DNA level. Turk. J. Agric. For. 34: 285-301.

Borrill, M., M. Kirby, and W.G. Morgan (1977). Studies in Festuca 11. Interrelationships of some putative diploid ancestors of the polyploid broad-leaved fescues. New Phytol. 78:661-674.

Bulifiska-Radomska, Z., and R. N. Lester (1986). Species Relationships in Festuca (Sect. Ovinae, Poaceae) Pi. Syst. Evol. 154: 175- 182.

Buntjer, J.B. (1999). Cross Checker Fingerprint analysis software v2.9, Wageningen University and Research Centre, The Netherlands.

Cheng, Y., K. Zhou, M.W. Humphreys, J.A. Harper, X. Ma, X. Zhang, H. Yan, and L. Huang (2016). Phylogenetic Relationships in the FestucaLolium Complex (Loliinae; Poaceae): New Insights from Chloroplast Sequences. Front. Ecol. Evol. 4: 89.

Chesnokov, Yu. V., and A.M. Artemyeva (2015) Evaluation of the Measure of Polymorphism Information of Genetic Diversity, Agricultural Biology, V. 50 (5): 571-578.

Cuyeu, R., B. Rosso, E. Pagano, G. Soto, R. Fox, and N.D. Ayub (2013). Genetic diversity in a world germplasm collection of tall fescue. Genet. Mol. Biol. 36 (2): 237-242.

Demiroğlu, G., H. Geren, B. Kir, and R. Avcıŏlu (2010). Performances of some cool season turfgrass cultivars in Mediterranean environment: II. Festuca arundinacea Schreb., Festuca ovina L., Festuca rubra spp. rubra L., Festuca rubra spp. trichophylla Gaud and Festuca rubra spp. commutata Gaud. Turk J Field Crops. 15 (2): 180-187.

Earl, D.A., and B.M. Von Holdt (2012). STRUCTURE HARVESTER: a website and program for visualizing STRUCTURE output and implementing the Evanno method. Conservation Genetics Resources. 4 (2) 359-361.

Evanno, G., S. Regnaut, and J. Goudet (2005). Detecting the number of clusters of individuals using the software STRUCTURE: a simulation study. Mol Ecol 14: 2611-2620.

Fasih, Z., M. Farshadfar, and H. Safari (2013). Genetic diversity evaluation of within and between populations for Festuca arundinacea by ISSR markers. Intl J Agri Crop Sci. 5 (13): 1468-1472.

Fjellheim, S., Z. Grieg, and O.A. Rognli (2004). Aflpmarker analyses of genetic structure in nordic meadow fescue (Festuca pratensis huds.). 
Tracing the origin of norwegian cultivars and local populations. Dev. Plant Breed. 11: 303308.

Gibson, D.J., and J.A. Newman (2001). Festuca arundinacea Schreber (F.elatior L.ssp. arundinacea (Schreber) Hackel). J. Ecol. 89: 304-324.

Guner, A. (2012). Turkey List of plants, vascular plants. ANG vakfi. S 74-79.

Habibi, B., M. Farshadfar, and H. Safari (2012). Evaluation of Genetic Diversity in 18 Genotypes of Alfalfa (Medicago Sativa) Using of Molecular ISSR Markers. Intl J Agri Crop Sci. 4-21:15731578.

Hand, M.L., N.O.I. Cogan, and J.W. Forster (2012). Molecular characterisation and interpretation of genetic diversity within globally distributed germplasm collections of tall fescue (Festuca arundinacea Schreb.) and meadow fescue ( $F$. pratensis Huds.). Theor Appl Genet. 124: 1127.

Hand, M.L., N.O.I. Cogan, A.V. Stewart, and J.W. Forster (2010). Evolutionary history of tall fescue morphotypes inferred from molecular phylogenetics of the Lolium-Festuca species complex. BMC Evol Biol. 10: 303.

Kumar, A., P. Mishra, S. C. Singh, and V. Sundaresan (2014). Efficiency of ISSR and RAPD markers in genetic divergence analysis and conservation management of Justicia adhatoda L., a medicinal plant. Plant Syst Evol. 300:14091420.

Lamare, A., and S.R. Rao (2015). Efficacy of RAPD, ISSR and DAMD markers in assessment of genetic variability and population structure of wild Musa acuminata colla. Physiol Mol Biol Plants. 21 (3):349-358.

Ma, Y. (2012). Genetic Characterization of Fine-leaved Festuca valesiaca Germplasm and Evaluation of Their Relationship to the F. ovina complex. M.Sc. thesis, 1352. Plant Science. Utah State University. USA.

Malik, C. P., and P.T. Thomas (1967). Cytological Relationships and Genome Structure of Some Festuca Species, Caryologia. 20: (1) 1-39.

Nadeem, M.A., A.A. Nawaz, Q. M. Shahid, Y. Doğan, G. Comertpay, M. Yıldız, R. Hatipoğlu, F. Ahmad, A. Alsaleh, N. Labhane, H. Ozkan, G. Chung, and F. S. Baloch (2018). DNA molecular markers in plant breeding: current status and recent advancements in genomic selection and genome editing. Biotechnol Biotec EQ. 32: (2) 261-285.

Nelson, C.J., K.H. Asay, and G. L. Horst (1975). Relationship of leaf photosynthesis to forage yield of tall fescue. Crop Sci. 15:476-478.
Ogle, D., M. Stannard, P. Scheinost, and S. L. John (2010). Plant guide for sheep fescue (Festuca ovina L.). USDA Natural Resources Conservation Service, Idaho and Washington Plant Materials Program.

Özpinar, H., C.O. Sabanci, A.A. Acar, S. Aksu, and İ. F. Niksarli (2014). Evaluation of Fescue (Festuca arundinacea Schreb. and Festuca rubra L.) populations grown under Aegean region conditions, Anadolu, J. of Aari. 24 (2): 32 - 40.

Peakall, R., and P.E. Smouse (2001). GenAlEx V5: Genetic Analysis in Excel. Population genetic software for teaching and research. Australian National University, Canberra, Australia.

Perrier, X., A. Flori, and F. Bonnot (2003). Methods for data analysis. In: Hamon P, Seguin M, Perrier X, Glazmann JC (eds) Genetic diversity of cultivated tropical plants. Science Publishers, Inc and Cirad, Montpellier. 31-63.

Pritchard, J.K., M. Stephens, and P. Donnelly (2000). Inference of population structure using multilocus genotype data. Genetics. 155: 945959.

Rahimi, M., I.M. Hervan, M. Valizadeh, F.D. Kajori, and F. Ebrahimpour (2014). Genetic Diversity among Wild and cultivated barley by ISSR Marker. Bull. Env. Pharmacol. Life Sci. 3 (10) 57-62.

Rahmati, H., M. Farshadfar, and H. Shirvani (2018). Study of Genetic Diversity of Festuca Arundinacea Based on ISSR Molecular Markers. J. Crop Breed. Vol. 9, No 24.

Reddy, M.P., N. Sarla, and E.A. Siddiq (2002). Inter simple sequence repeat (ISSR) polymorphism and its application in plant breeding, Euphytica 128: 9-17.

Rouf Mian, M.A. M.C., Saha, A. Hopkins, and Z.Y. Wang (2005). Use of tall fescue EST-SSR markers in phylogenetic analysis of cool-season forage grasses. Genome 48, 637-647.

Sheidai, M., and E. Bagheri-Shabestarei (2007). Cytotaxonomy of some Festuca species and populations in Iran. Acta Bot Croat. 66 (2):143151.

Šmarda, P., J. Müller, J. Vrána, and K. Kočí1(2005). Ploidy level variability of some Central European fescues (Festuca subg. Festuca, Poaceae). Biologia Bratislava. 60 (1): 25-36.

Sokal R.R., and C.D. Michener (1958). A statistical method for evaluating systematic relationships. Univ. Kans. Sci. Bull. 28:1409-1438.

Stukonis, V., R. Armonienè, N. Lemežienè, V. Kemešytė and G. Statkevičiūtè (2015). Identification of Fine-Leaved Species of Genus Festuca By Molecular Methods. Pakistan J. Bot. 47 (3): 1137-1142. 
Szenejko, M., P. Smietana, and E. Stepien (2016). Genetic diversity of Poa pratensis L. depending on geographical origin and compared with genetic markers. PeerJ 4:e2489.

Talukder, S.K., P. Azhaguvel, K. Chekhovskiy, and M.C. Saha (2018). Molecular discrimination of tall fescue morphotypes in association with Festuca relatives. PLoS ONE. 13(1): e0191343.

Tehrani, M.S., M. Mardi, J. Sahebi, C. P. Pilar, and A. Diaz-Perez (2009). Genetic diversity and structure among Iranian tall fescue populations based on genomic-SSR and EST-SSR marker analysis. Plant Syst Evol. 282:57-70.

Xu, W.W., and D.A. Sleper (1994). Phylogeny of tall fescue and related species using RFLPs Theor Appl Genet. 88:685-690.
Zhang, C., J. Zhang, Y. Fan, M. Sun, W. Wu, W. Zhao, $X$. Yang, L. Huang, Y. Peng, X. Ma, and X. Zhang (2017). Genetic Structure and EcoGeographical Differentiation of Wild Sheep Fescue (Festuca ovina L.) in Xinjiang, Northwest China. Molecules. 22, 1316.

Zhu, C., M. Gore, E.S. Buckler, and J. Yu (2008). Status and Prospects of Association Mapping in Plants. The Plant Genome J. 1:5-20.

Zietkiewicz, E., A. Rafalski, and D. Labuda (1994). Genome fingerprinting by simple sequence repeat (SSR)-anchored polymerase chain reaction amplification. Genomic. 20 (2):176-83. 